\title{
A Review of PHIL Testing for Smart Grids-Selection Guide, Classification and Online Database Analysis
}

\author{
Eduardo García-Martínez ${ }^{1, * \mathbb{C}}$, José Francisco Sanz ${ }^{2}$, Jesús Muñoz-Cruzado ${ }^{1}$ and \\ Juan Manuel Perié 1 \\ 1 CIRCE-Research Centre for Energy Resources and Consumption, 50018 Zaragoza, Spain; \\ jmunoz@fcirce.es (J.M.-C.); jmperie@fcirce.es (J.M.P.) \\ 2 Instituto Universitario de Investigación CIRCE (Fundación CIRCE-Universidad de Zaragoza), \\ 50018 Zaragoza, Spain; jfsanz@unizar.es \\ * Correspondence: edugm@fcirce.es; Tel.: +34-976-976-859
}

Received: 23 January 2020; Accepted: 19 February 2020; Published: 25 February 2020

\begin{abstract}
The Smart Grid is one of the most important solutions to boost electricity sharing from renewable energy sources. Its implementation adds new functionalities to power systems, which increases the electric grid complexity. To ensure grid stability and security, systems need flexible methods in order to be tested in a safe and economical way. A promising test technique is Power Hardware-In-the-Loop (PHIL), which combines the flexibility of Hardware-In-the-Loop (HIL) technique with power exchange. However, the acquisition of PHIL components usually represents a great expense for laboratories and, therefore, the setting up of the experiment involves making hard decisions. This paper provides a complete guideline and useful new tools for laboratories in order to set PHIL facilities up efficiently. First, a PHIL system selection guide is presented, which describes the selection process steps and the main system characteristics needed to perform a PHIL test. Furthermore, a classification proposal containing the desirable information to be obtained from a PHIL test paper for reproducibility purposes is given. Finally, this classification was used to develop a PHIL test online database, which was analysed, and the main gathered information with some use cases and conclusions are shown.
\end{abstract}

Keywords: Power Hardware-In-the-Loop (PHIL); Smart Grid test bed; review; database; Digital Real-Time Simulator (DRTS); Power Amplifier (PA)

\section{Introduction}

In recent years, Smart Grids have been connected to the electric grid widely, increasing the number and diversity of the systems installed in the electric grid [1]. Smart Grid devices have to communicate and operate among themselves. Therefore, they need to be able to take their own decisions, in order to efficiently deliver sustainable, economical and secure electricity supplies [2]. As a consequence of this increase in complexity [3-5], the future power system modelling, analysis and design meet new challenges. To ensure the proper operation of these new technologies, achieving renewable electric grid integration and guaranteeing a sustainable and secure electricity supply, research in affordable test systems is needed [6-9].

Figure 1 compares all available test system methods for Smart Grid applications in terms of fidelity, coverage and cost. Simulation tests allow a wide test coverage at a low cost, but the test fidelity is compromised by the accuracy between the model and the real system.

Controller Hardware-in-the-Loop (CHIL) systems use a Digital Real-Time Simulator (DRTS) and physical interface $[10,11]$. They allow the running of models in order to test the device's hardware and 
software. Therefore, CHIL tests have slightly less test coverage than software simulation due to the real-time limitation, but improve the test fidelity feature.

PHIL systems add on a Power Amplifier (PA) stage to classic CHIL systems. Consequently, PHIL systems achieve great test fidelity because they do not work with the Hardware-Under-Test (HUT) model, but with the real system. They will be limited by the PA working range and by the real-time system model.

Another option is the use of a specific test-bed designed ad-hoc considering the HUT application and requirements, scaling down the power of the experiment. This test type has approximately the same test fidelity as PHIL systems but, unfortunately, it is designed for very special cases reducing its reuse, which eventually could imply a higher final cost.

Finally, tests made on the full system directly show very accurate results, but they do not have any flexibility. They prevent the possibility of wide test coverage planning, and add the risk of real system breakdown during the experiment.

For Smart Grid testing, the test technique with the best trade-off between test fidelity and test coverage is PHIL. Laboratories which acquire a DRTS to conduct a CHIL test also have the opportunity to carry out offline simulations more quickly than workstations. Moreover, laboratories which acquire a DRTS and a PA for PHIL testing could perform CHIL and/or an offline simulation too.

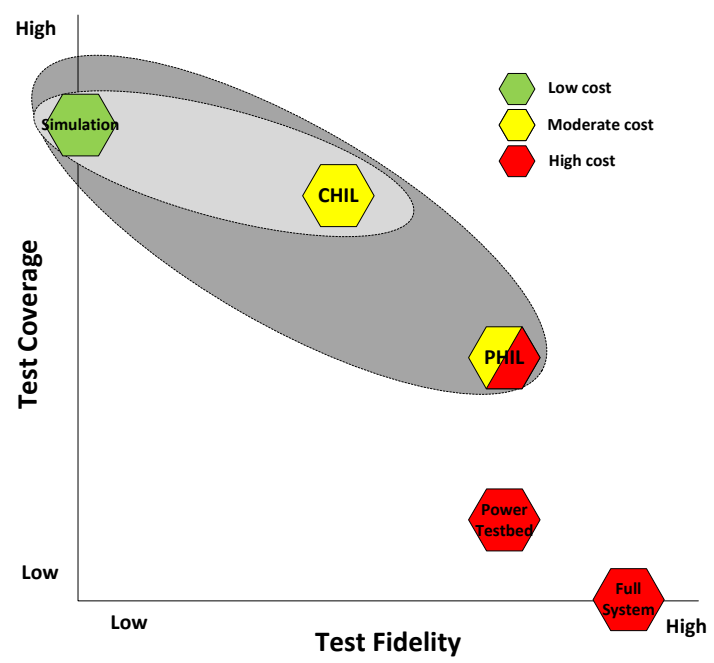

Figure 1. Smart Grid test beds and their comparative (based on [12]): simulation, CHIL, PHIL, power test bed and full system.

Figure 2 shows a typical PHIL configuration. The DRTS holds a mathematical model of the simulated system executed in real-time, sending at every time-step the output set-point to the PA (so-called power interface). This PA changes the set-point information received into real voltage or current, and the HUT reacts to its new value. This reaction is measured by the PA and by the DRTS sensors, adding it to the mathematical model to calculate the next step. 


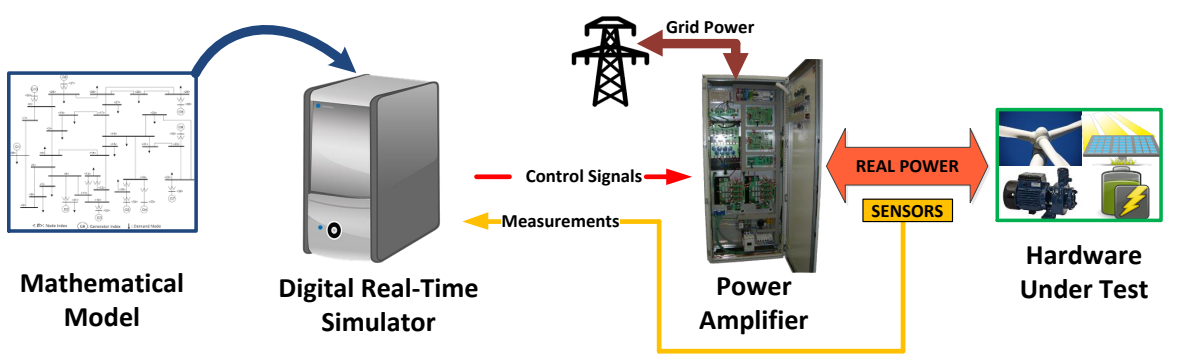

Figure 2. PHIL basic structure, identifying most representative subsystems: Mathematical model, Digital Real-Time Simulator (DRTS), Power Amplifier (PA), and Hardware Under Test (HUT).

PHIL tests can be classified in voltage-type or current-type, which will vary the closed-control block diagram of the PHIL test. If the PHIL test is current-type, it means that the PA works as a current source, thus the DRTS has to send the current set-point to the PA and measure the voltage response of the HUT. However, if the PHIL test is voltage-type, the PA works as a voltage source and the DRTS has to send the voltage set-point to the PA and measure the current response of the HUT. The work in [13] is an example of PHIL test current-type and that in [14] is an example of PHIL test voltage-type.

Different PHIL applications to test Smart Grids are summarised in [9]. These include, among others, loss-of-mains detection, energy management, wind integration, volt-VAR control, harmonic analysis and cyber-physical renewable energy in-feed testing. Due to this versatility, an increase in the use of PHIL test beds is foreseen in electrical and renewable laboratories. However, in the market, there is not a unique solution which can perform all the tests that can be found in the literature. For that reason, and considering the initial cost of the two main systems (DRTS and PA), laboratories need to clarify their objectives in order to find the best solution for them. Furthermore, the setting up of the experiments still has some difficulties [15].

The main goal of this paper is to develop a schematic guide in order to help laboratories to choose the best PHIL elements for each type of HUT, each test to be carried out and each objective to be achieved with the test. Another aim is to increase and facilitate the reproducibility of PHIL experiments, which can boost the development of Smart Grid systems. For that purpose, a classification scheme is proposed regarding useful information to be gathered from a PHIL test in order to complement manufacturer information. Furthermore, this classification was used to create an online database, which contains a review of state-of-the art PHIL tests. As a result, this database provides essential information for reusability and system selection.

This paper is organised as follows. Section 2 introduces the system selection guide to choose PHIL elements, based on information that could be obtained from manufacturers and the state-of-the art. A classification is presented in Section 3, which includes most relevant information from these tests to ensure reusability. In Section 4, the PHIL test online database is briefly presented and the main gathered information is analysed. This online database is employed in Section 5 to present a use case example of PHIL system selection for Smart Grids. Finally, conclusions are given in Section 6.

\section{PHIL System Selection Guide}

PHIL systems are made up of several items that could be selected independently. Figure 3 shows a schematic guide of the needed selection steps. In this diagram, the marks "** and "\#" show if the information is in the manufacturer datasheet and the state of the art, respectively. 


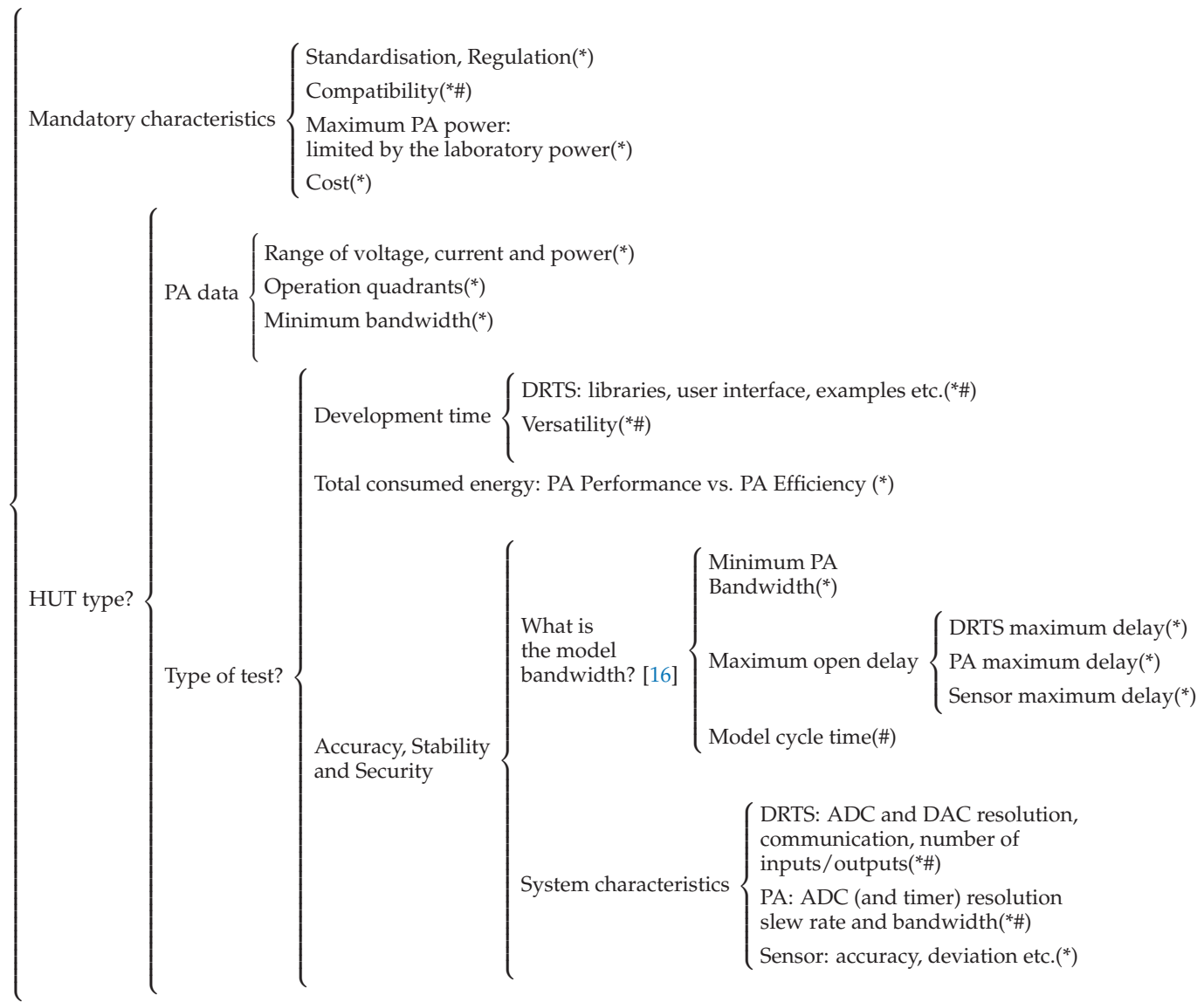

Figure 3. PHIL system guide scheme selection (“*” Manufacturer information; "\#” State-of-the-art information).

There are some mandatory characteristics to be considered before starting the PHIL system selection guideline. EMC regulation compliance is mandatory to avoid problems with the rest of the laboratory equipment. In addition, the research facility could already have a DRTS or a PA, so future acquisitions have to be compatible with these devices. Moreover, the maximum power of the PA may not be more than the maximum power of the facility. Finally, the laboratory budget (cost) narrows the possible elements list down to complete the test bed.

After the binding aspects, the HUT type to be tested is the best starting point to select the PHIL test bed. The HUT application and characteristics will define the required PA features. Below, the most important characteristics are pointed out, whose value is usually provided by the manufacturer datasheet.

- $\quad$ The range of voltage, current and power that the PA has to deliver to test HUT at nominal behaviour. - The operation quadrants, depending on the apparent HUT nominal power.

- The minimum bandwidth, e.g., Amitkumar et al. [17] suggested that the PA needs to have five times more bandwidth than the test inverter's current loop for an accurate emulation.

Furthermore, the HUT type establishes the types of tests to be done, which define some important features of PHIL systems. The development time to carry out a test is an important feature to take into account too. In addition, the DRTS plays an important role in speeding up the experiments. DRTS features, such as a user-friendly interface, libraries with verified models of the elements to be simulated and application examples provided by the manufacturer or found in the literature, could help in this purpose. Finally, the versatility of DRTS and PA can economise the time to perform the experiment. 
As can be seen in Table 1, the PA choice is a trade-off between performance and efficiency. For this reason, depending on the required accuracy and the total consumed energy during experiments, laboratories could decide between the two main PA families: linear amplifier and switched mode amplifier.

Table 1. Advantages and disadvantages of different types of power amplifiers $[18,19]$.

\begin{tabular}{|c|c|c|}
\hline & Advantages & Disadvantages \\
\hline Switched amplifier & $\begin{array}{l}\text { - Less expensive } \\
\text { - Highest efficiency } \\
\text { - Great flexibility (can operate both } \\
\text { as current and voltage amplifier) } \\
\text { - Smallest size } \\
\text { - Lowest operating temperature } \\
\text { - Low-power factor handling }\end{array}$ & $\begin{array}{l}\text { High delay and lower } \\
\text { accuracy than linear } \\
\text { amplifier }\end{array}$ \\
\hline Linear amplifier & $\begin{array}{l}\text { - Very high dynamic performance } \\
(0-5 \mathrm{kHz} \text { bandwidth or more) } \\
\cdot \text { Short time delay } \\
\text { - Easy transfer function with fewer } \\
\text { stability issues } \\
\cdot \text { Highest crest-factor } \\
\text { - Highest start-up surge current }\end{array}$ & $\begin{array}{l}\text { - Very low power efficiency } \\
\text { - Low power output (as } \\
\text { a consequence of the first } \\
\text { one) } \\
\text { - Biggest size }\end{array}$ \\
\hline $\begin{array}{l}\text { Synchronous } \\
\text { generator amplifier }\end{array}$ & - High power output & $\begin{array}{l}\text { Only for testing where } \\
\text { balanced three phase power } \\
\text { is required } \\
\text { - Higher level of time delay } \\
\text { and the lowest accuracy }\end{array}$ \\
\hline
\end{tabular}

Accuracy, stability and security of PHIL tests are strongly related. Increasing accuracy also increases test stability and vice-versa, which boosts the overall security. An important study for PHIL accuracy evaluation can be found in $[20,21]$.

Before performing the test, laboratories have to know the highest frequency in the model that has to be closed-loop controlled, which will define what the simulated model bandwidth is [16]. For example, to simulate the electric grid transient, a maximum frequency of $2 \mathrm{kHz}$ is usually taken [22]. More examples can be found in [16,23-25] where the time-step requirements of the most typical real-time tests are described.

To ensure that the PHIL test bench can achieve the desired frequency, it is proposed to follow the procedure detailed in [16], which provides the model cycle time, the PA bandwidth and the maximum open delay depending the closed-loop controlled model frequency. The authors set forth that, to have a stable experiment in closed-loop, the total open-loop phase shift at the desired frequency has to be less than $-75^{\circ}$. This open-loop phase shift is the sum of the maximum open delay $\left(D t_{X}\right)$ of each subsystem in the direct chain PHIL control and the PA transfer function, which is shown in Figure 4. The phase margin at the desired frequency guarantees stability, using a regulator with a pole located at the origin. 


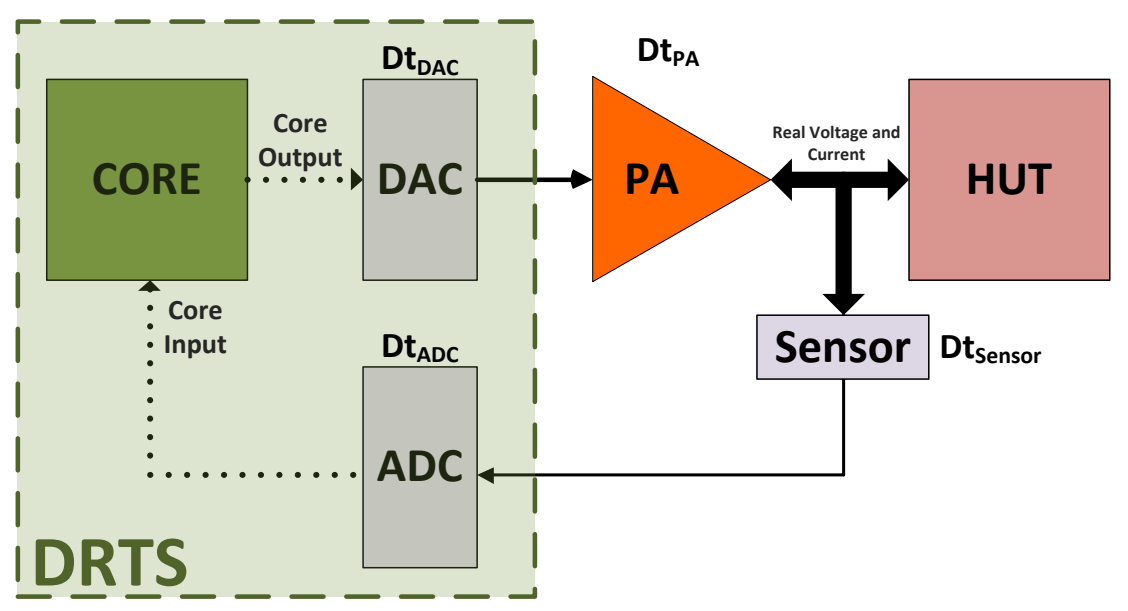

Figure 4. A PHIL set-up with analogue communication (based on [16]).

The equations given by Lemaire et al. [16] to know the maximum open delay, the PA bandwidth and the model cycle time are listed below:

- Maximum open delay: Figure 4 shows a set-up where the set-point and measurements are sent with an analogue signal. The total open-loop delay between the DRTS output and input is the sum of each delay in the loop:

$$
D t_{\text {open_loop }}=D t_{D A C}+D t_{P A}+D t_{\text {Sensor }}+D t_{A D C}
$$

The maximum delay between "Core Output" and "Core Input" to ensure an open-loop phase shift less than $-45^{\circ}$ has to be:

$$
D t_{\text {open_loop }}<\frac{45^{\circ}}{360^{\circ} \cdot f_{\text {Model }_{B W}}}=\frac{1}{8 \cdot f_{\text {Model }_{B W}}}
$$

- Minimum PA bandwidth: The open-loop phase shift at the PA frequency bandwidth is $-45^{\circ}$. To obtain, at the most, an open-loop phase shift of $-30^{\circ}$, the minimum bandwidth of the PA has to be at least 1.5 times wider than the highest frequency of the model to be simulated:

$$
P A_{B W_{f_{(3 d B)}}}>1.5 \cdot f_{\text {Model }_{B W}}
$$

- Model cycle time: The maximum time-step that the simulator has to achieve depends on the highest dynamic or frequency bandwidth of the simulated model. To generate this highest frequency, Lemaire et al. [16] determined that the minimum time step must be at least 25 times less than the inverse of the desired frequency:

$$
\text { Time_Step } \text { Simulation }_{2}<\frac{1}{25 \cdot f_{\text {Model }_{B W}}}
$$

Figure 5 describes graphically Equations (2)-(4) and shows an example of the characteristics needed to test an electric grid transient, whose maximum frequency of interest is $2 \mathrm{kHz}$. In this case, the minimum bandwidth of the PA is $3 \mathrm{kHz}$, the time step has to be less than $20 \mu$ s and the maximum open-loop delay less than $60 \mu \mathrm{s}$. 


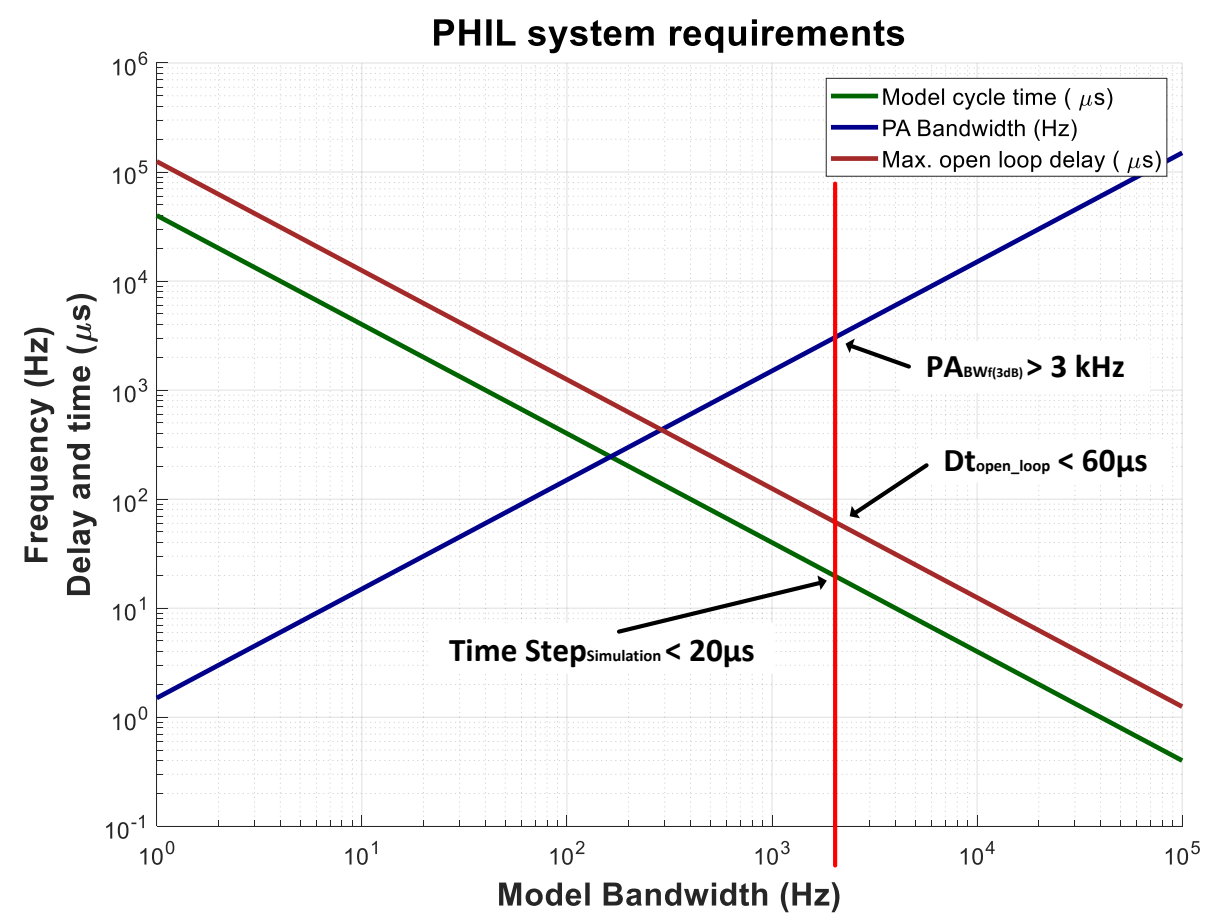

Figure 5. PHIL system requirements depending the bandwidth of the model to test [16]. In this case, an example of an electric grid transient test is given, for which the maximum frequency of interest is $2 \mathrm{kHz}$.

Finally, when the elements selection is focused on only two or three systems from the entire spectrum, a deeper comparison considering the main system characteristics is advisable. For example, parameters such as the resolution of the ADC-DAC, types of communications, number of inputs/outputs, compatibility with other simulation systems, etc. could be used for this comparison. To compare different PA systems, parameters such as the voltage and/or current bandwidth, slew rate, efficiency, current and voltage THD, etc. would be the factors that tip the balance. The decision between the different kind of sensors is usually more simple as it is a more mature technology.

\section{Information Classification for Reusability Purposes}

Reproducibility is essential in scientific reports, saving laboratories both time and effort. According to Vandewalle et al. [26]: "A research work is called reproducible if all information relevant to the work, including, but not limited to, text, data and code, is made available, such that an independent researcher can reproduce the results". It is understood that sometimes it is not possible to show all the PHIL test information because there are conflicts of interest. Furthermore, in the case of PHIL testing, often it is not possible to repeat exactly the same experiments, due to the difficulty of replicating all the boundary conditions. Therefore, regarding the use-case complexity, Vandewalle et al. [26] recommended the reusability of experiments rather than reproducibility.

Therefore, it is crucial to identify the correct information from a scientific report, in order to be able to provide the reusability of the PHIL test. Although the information organisation could be done in several ways, the same or equivalent information should be considered. In the following, the possible classification of the desirable information to be obtained from a PHIL test paper is outlined with the aim of reusing the test data. The information is organised into nine groups according to our criteria and experience. Each group has its own particularities, and here the most important ones are shown. In addition to the technical data, more subjective information is proposed in order to give a complete understanding of the described experiments. 


\section{Real-Time Simulator}

- $\quad$ DRTS model and reference to the web page where the datasheet could be found.

- If the DRTS it is not a commercial one:

* Simulation environment: visual characteristics, examples, library models etc.

* DAC and ADC resolution.

* Hardware and software delays.

* Different types of communication.

* Solver types.

\section{Power Amplifier}

- $\quad$ PA model and a reference to the web page where the datasheet could be found.

- Amplifier type: switched or linear.

- If the power amplifier system is not a commercial one:

* Working quadrants.

* Maximum power.

* Voltage and/or current bandwidth.

* Voltage and/or current slew rate.

* Efficiency.

* Voltage and current THD.

* Dimensions and weight.

* Accuracy, ripple etc.

\section{Hardware Under Test}

- General description.

- $\quad$ Model and reference to the web page where the datasheet could be found.

\section{Simulated model}

- $\quad$ Time step.

- $\quad$ Model and a reference to the web page where the datasheet could be found.

- Interface Algorithm (IA) used and why.

- Power range and bandwidth.

- Libraries and/or standard models used.

- $\quad$ A block diagram figure is advisable.

\section{Test Results}

- Graphs and oscilloscope captures to check:

* Desired and obtained output.

* Accuracy and stability.

* Slew rate.

* Ripple.

- Problems encountered during the test and how they have been solved.

\section{DRTS and PA interconnection}

- Analogue communication:

* ADC resolution in both systems.

* Delays in acquisition voltage.

* Sample frequency.

* Voltage range.

- Digital communication:

* Standard used.

* Baud rate.

* Set-point and measurement resolution.

- Sensor types used and their main characteristics.

Overall PHIL test 
- A figure scheme with the PHIL test bench.

- A photograph of the complete PHIL test bench during an experiment.

\section{PHIL test Motivation}

- Type of test and its purpose.

- References of the different kind of test consulted.

- Reference to another PHIL test done in the laboratory.

\section{Final Conclusion}

- $\quad$ Determine the PHIL set-up usefulness for test purposes.

- Clarification of the test bed limits.

- Possible improvements for future testing.

\section{PHIL Tests Database Analysis}

PHIL reviews found in the literature $[9,23,27-32]$ mainly focus on technical aspects which help to improve the overall PHIL performance. However, current state-of-the-art reviews do not provide enough information to help laboratories choose the PHIL systems efficiently, and to facilitate the reusability of PHIL tests. To give a tool for laboratories to move towards the desired objectives, an online database about the state-of-the-art PHIL tests was created. For its development, the information classification of the previous section was used as a guide. To the authors' best knowledge, no similar PHIL tests database review has been published yet in the literature with this level of scope and detail.

Table 2 shows the different tables of the database in every column and their fields. More detailed information about the online database can be found in [33]. 
Table 2. Fields of the different tables database designed to help in the PHIL system selection process, and to facilitate the PHIL tests reproducibility [33].

\begin{tabular}{|c|c|c|c|c|}
\hline Papers & Power Amplifier & DRTS & HUT Device & Companies-Universities \\
\hline Year & Model & Model & Device & Company-University Name \\
\hline Title & Power $(\mathrm{kW})$ & Companies-University & HUT Types & Research centre \\
\hline Authors & Voltage BW (Hz) & Link & Companies-University & Company \\
\hline Companies-University & Current BW (Hz) & Notes & Add Date & University \\
\hline Summary & Accuracy (pct) & Hardware & Added By & Link \\
\hline Why and what for & Power Factor & Host OS & Revision Date & Add Date \\
\hline Step Time ( $\mu \mathrm{s})$ & Width (mm) & Target OS & Permission User & Added By \\
\hline DRTS & Height (mm) & Application Software & Last Modification Date & Revision Date \\
\hline Test Power (kVA) & Depth (mm) & Communication, Protocols, I/O & Last Modification By & Permission User \\
\hline Interconnection Method & Weight (kg) & Application & & Last Modification Date \\
\hline Algorithm & Power Density $\left(\mathrm{kW} / \mathrm{dm}^{3}\right)$ & ADC bit & & Last Modification By \\
\hline Results & Specific Power (kW/kg) & ADC delay & & \\
\hline Conclusions & Voltage Range (V) & Minimum Time Step ( $\mu \mathrm{s})$ & & \\
\hline Notes & Current Range (A) & Add Date & & \\
\hline Power Amplifier & Efficiency (pct) & Added By & & \\
\hline HUT Type & Voltage Ripple (pct) & Revision Date & & \\
\hline Simulated System & Price $(€)$ & Permission User & & \\
\hline Test Objective & Slew Rate $(V / \mu s)$ & Last Modification Date & & \\
\hline Reference Latex & Delay ( $\mu \mathrm{s})$ & Last Modification By & & \\
\hline HUT Device & Communication & & & \\
\hline Link & Quadrants & & & \\
\hline Add Date & Modularity & & & \\
\hline Added By & Portability & & & \\
\hline Revision Date & Security & & & \\
\hline Permission User & Standard & & & \\
\hline Last Modification Date & Link Web & & & \\
\hline Last Modification By & Attachment & & & \\
\hline & Notes & & & \\
\hline & Companies-University & & & \\
\hline & Add Date & & & \\
\hline & Added By & & & \\
\hline & Revision Date & & & \\
\hline & Permission User & & & \\
\hline & Last Modification Date & & & \\
\hline & Last Modification By & & & \\
\hline
\end{tabular}


To obtain the most important and used systems and techniques of the PHIL tests developed in the literature, an analysis of the online database information is described below. Moreover, complementary material about these systems and techniques, which are not included in the database, are shown.

\subsection{Digital Real Time Simulator}

The current state of the technologies used in the real-time simulation industry for power system application is shown in [23]. The complete table, with a summary of salient features and options of the most commonly used real-time digital simulators in both industry and academia, is remarkable. All of these DRTSs can be used for both HIL and PHIL.

In the online database, only four DRTSs are used to perform all the included PHIL experiments. These DRTSs and the published papers where they were used are listed below:

- OPAL-RT ([34]): [15,17,35-46]

- $\quad$ RTDS ([47]): [13,14,48-72]

- $\quad \operatorname{VTB}([73]):[74]$

- $\quad \operatorname{Hypersim~([75]):~[76]~}$

There are also more commercial DRTSs which could be used for HIL and PHIL tests [23]. However, since PHIL is a recent technique, examples of all of them have not been found. For this reason, they have not been included in the database.

Furthermore, in the literature, some examples of ad-hoc real-time simulators can be found. These ad-hoc systems often run commercial simulation software and are used to perform HIL, but references to PHIL tests have not found for all of them. Therefore, they have not been included in the database. However, they could be an option for PHIL tests, thus a list of these ad-hoc DRTSs, depending on their hardware system and the reference which describes them, are shown below:

- CPU: [77-81]

- DSP: [82-88]

- $\quad$ FPGA: [89-94]

\subsection{Hardware under Test (HUT)}

HUT is the most used abbreviation to designate the system to be tested. Besides, it can be called Device Under Test (DUT) $[30,35,37,53,95,96]$ or Equipment Under Test (EUT) $[97,98]$. This element, together with the kind of test to be done and its objective, define the main characteristics to be considered in the PHIL test bench.

One of the most important online database uses is to search for the desired HUT to be tested and to know what the main element choices of the scientific community are, checking their main problems and results. As an example, Table 3 shows a database sample classified by HUT groups, denoting the type of IA used, the simulated system in the DRTS and its time step, the maximum power reached by the PA and the objective of the test. 
Table 3. Database classification according the type of HUT used in the PHIL test.

\begin{tabular}{|c|c|c|c|c|c|c|}
\hline HUT & Reference & Algorithm & Simulated System & Test Objective & Step Time $(\mu s)$ & Test Power (kVA) \\
\hline Battery Energy Storage System (BESS) & [38] & - & Electric Grid & Test Simulated System & 50 & 2 \\
\hline Car: FTP-72 driving cycle & [35] & ITM & Lithium Battery & Check PHIL Behaviour & 10 & 0.345 \\
\hline Linear Circuit; PV Microinverter & [49] & ITM & Electric Grid & Check PHIL Behaviour & 10 & 0.052 \\
\hline Nonlinear circuit; Linear Circuit & [48] & TLM & Electric Grid; Electric Ship & Check PHIL Behaviour & 60 & 16.7 \\
\hline PV Inverter & [50] & ITM & Electric Grid & $\begin{array}{l}\text { Check PHIL Behaviour; } \\
\text { Test HUT }\end{array}$ & 50 & 3 \\
\hline PV Inverter & [14] & $\begin{array}{l}\text { ITM } \\
\text { DIM }\end{array}$ & Electric Grid & Check PHIL Behaviour & - & 1 \\
\hline PV Inverter & [51] & ITM & Electric Grid & Check PHIL Behaviour & - & 0.8 \\
\hline Linear Circuit & [37] & ITM & Electric Grid & Check PHIL Behaviour & 10 & 0.1 \\
\hline $\begin{array}{l}\text { SFCL (Superconducting Fault Current } \\
\text { Limiter) }\end{array}$ & [76] & ITM & Short-Circuit & Test HUT & 30 & - \\
\hline Smart Transformer (ST) & [13] & ITM & Electric Grid & $\begin{array}{l}\text { Test HUT; Test Simulated } \\
\text { System }\end{array}$ & 45 & 2 \\
\hline
\end{tabular}




\subsection{Power Amplifier}

Three different types of PA are compared in [19], and their main characteristics classification are shown in Table 1. In the case of switched amplifiers, which are non-linear interface converters, it can be useful to know what considerations have been made by the authors in every test about the accuracy and stability of PHIL [99]. To give to the reader an overview of the most important PA included in the online database, the main PA manufacturers and the published papers where they were used are listed below:

- $\quad$ Linear Amplifier:

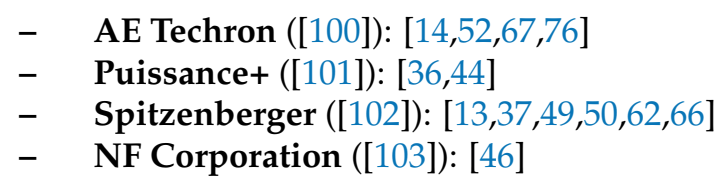

- $\quad$ Switched Amplifier:

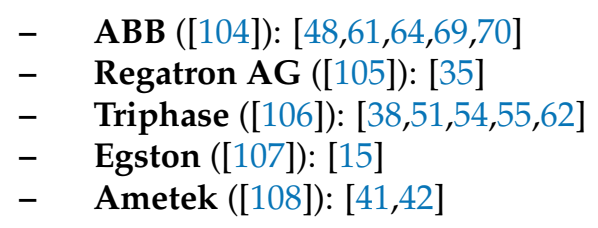

Furthermore, several research papers of new types of PA for PHIL purposes can be found in [96,98,109-113]. Usually, these new systems are switched amplifier instead of linear amplifier, due to the fact that it is a more efficient technology and the specific and density power is clearly higher. These PAs have not been included in the database, but it is expected that this technology will be the new generation of PA in the future.

\subsection{Interface Algorithm}

In [31], a review of IA with references to several discussions about their relative strengths and weaknesses is described. Furthermore, another review is done in [114], where the stable area of the main IAs is calculated. The online database shows that the most used IAs are the Ideal Transformer Model (ITM) and the Damping Impedance Method (DIM). The first one is used because of its accuracy and ease of implementation, but it could have some stability problems. The second one is increasingly used because, if the HUT impedance is estimated accurately, this IA achieves very good stability and accuracy on the simulation side [115].

\subsection{Communication}

The online database shows that the main type of communication used between the DRTS and PA is an analogue voltage signal of $\pm 10 \mathrm{~V}$. The advantage compared with a digital one is the interoperability between systems of different manufacturers. Nevertheless, it is more vulnerable to electromagnetic noise, which could reduce the total accuracy of the PHIL test.

There are few examples of digital communication and some efforts are being made by manufacturers. In [116], a serial communication between the DRTS and the PA has been used. Other communication protocols such as EtherCAT or ORION have been implemented in [34], which can be used to communicate with PA such as those in $[106,107]$.

\section{Smart Grid PHIL System Sizing}

To give an example of the possibilities offered by the previous classification, a use case for the selection of PHIL systems for Smart Grid tests using the online database is presented below. The needed PHIL test bed targets and characteristics of the use case example are: 
- HUT types: Grid side power electronics.

- $\quad$ Type of tests: Renewable energy and storage systems integration.

- $\quad$ Simulated System: Electric grid [117].

- $\quad$ Model bandwidth: $2 \mathrm{kHz}$ (step time of $50 \mu \mathrm{s}$ ).

- Laboratory maximum power: $100 \mathrm{~kW}$.

To achieve this purpose, the online database could show the solutions that other laboratories have developed for a similar objective. After downloading the database and entering as a guest in the login page shown, the access to "Table Reports" in the "Check Information" group shows the literature PHIL database experiments. A table filtering process using the fields "Simulated Systems", "Test Power" and "Step Time" gives the result shown in Table 4. The laboratory could get the following valuable information from this table:

1. There are two main DRTS companies that the scientific community uses to simulate an electric grid with a high number of nodes in real-time. It seems that there are not so many options in the market to simulate this kind of complex electric grid in real-time.

2. There are no tests in which a time step below $50 \mu$ s to simulate an electric grid in real-time is used. Therefore, if the test bed target changes and the model bandwidth increases, undesirable problems could appear.

3. The main interests of the laboratories are to know how the PV inverters and storage systems will behave in each electric grid. The test of another kind of grid side power electronics system will need a more detailed study. A less restrictive database filtering process, with the purpose of obtaining more results, could help to find more information.

4. Both linear and switched amplifiers are used. Consequently, the used PA topology will depend on other factors such as price.

5. More than half of the reports searched for were published during the last year. It shows that the state of the art is up-to-date and, therefore, the conclusions are more reliable.

After this quick process, the Smart Grid laboratories could have an overview of the main systems and the possibilities of developing their PHIL test bed. More database fields, which are not shown in Table 4 for readability reasons, could help in the selection process, such as the algorithm, results or conclusions. 
Table 4. Database query result for a Smart Grid application; Filtering process using the fields "Simulated Systems", ,Test Power" and "Step Time".

\begin{tabular}{|c|c|c|c|c|c|c|c|}
\hline Simulated System & HUT Type & Year & Step Time $(\mu s)$ & DRTS & Power Amplifier & Test Power (kVA) & Reference \\
\hline Electric Grid & $\begin{array}{l}\text { Distributed Energy } \\
\text { Storage Systems } \\
\text { (DESS) }\end{array}$ & 2010 & 50 & Opal-RT & Not shown & 5 & [39] \\
\hline Electric Grid & $\begin{array}{l}\text { Virtual } \\
\text { Synchronous } \\
\text { Generator (VSG) }\end{array}$ & 2011 & 50 & RTDS & Triphase (no model specified) & - & [55] \\
\hline Electric Grid; Electric Grid & PV Inverter & 2012 & 50 & RTDS & Triphase (no model specified) & 0.95 & [54] \\
\hline Electric Grid & Generator & 2015 & 100 & Labview & Not shown & 1.6 & [81] \\
\hline $\begin{array}{l}\text { Electric Grid; Electric } \\
\text { Motor/Generator; On Load } \\
\text { Tap Changer (OLTC) }\end{array}$ & $\begin{array}{l}\text { PV Inverter; Wind } \\
\text { Inverter }\end{array}$ & 2016 & - & RTDS & $\begin{array}{l}\text { Triphase (no model specified); } \\
\text { Spitzenberger\&Spies (no } \\
\text { model specified) }\end{array}$ & 3 & [62] \\
\hline Electric Grid & PV Inverter & 2017 & - & RTDS & $\begin{array}{l}\text { AE Techron (no model } \\
\text { specified) }\end{array}$ & 0.3 & [67] \\
\hline Electric Grid & PV Inverter & 2017 & - & RTDS & $\begin{array}{l}\text { Spitzenberger\&Spies } \\
\text { model specified) }\end{array}$ & 3 & [66] \\
\hline Electric Grid & $\begin{array}{lr}\text { Linear } & \text { Circuit; } \\
\text { Physical } & \text { Analog } \\
\text { Subsystem } & \text { (PAS); } \\
\text { Generator } & \end{array}$ & 2017 & 50 & RTDS & Ad-hoc (non-commercial) & 50 & [60] \\
\hline Electric Grid & PV Inverter & 2017 & - & RTDS & 7224 (AE Techron) & 1 & [14] \\
\hline Electric Grid & $\begin{array}{ll}\text { Battery } & \text { Energy } \\
\text { Storage } & \text { System } \\
\text { (BESS) } & \end{array}$ & 2017 & 50 & Opal-RT & PM15I60F60 (Triphase) & 2 & [38] \\
\hline
\end{tabular}




\section{Conclusions}

The Smart Grid is increasing the electric grid complexity and, therefore, flexible test system methods are needed to ensure its stability and security. An emerging test technique is Power Hardware-In-the-Loop (PHIL), which will play a major role in the development of the Smart Grid. To help laboratories set PHIL facilities up, this paper presents a schematic diagram selection guideline depending on the type of HUT and test. This scheme shows that the manufacturer data are needed as much as the state-of-the-art information to select the proper systems. However, not all the scientific reports about PHIL tests contain the information needed for the system selection, and, therefore, for its reproducibility. Consequently, a classification proposal of the desirable information that should be extracted from a PHIL test paper to guarantee the reproducibility of the experiments is suggested. This could help in the reusability of the test data and in the improvement of the PHIL state of the art. This classification has been organised into nine groups, based on our criterion and experience. It contains technical aspects, as well as more subjective information, which could aid in the full test comprehension.

To give a tool to laboratories for PHIL system selection and for PHIL test data reusability, a PHIL review online database is presented. This database was analysed to obtain the most valuable and general information for researchers and laboratories. The feasibility of this tool was checked showing a use case oriented towards Smart Grid application. Several results were drawn from this use case. First, there are only a few options on the market to simulate in real-time complex electric grids in real-time with a time-step of $50 \mu \mathrm{s}$. Another point is that the main interest of the laboratories is to test the behaviour of PV inverters and storage systems. Moreover, both linear and switched amplifiers are used to test the same HUT. Finally, PHIL tests have become more used in recent years. Furthermore, in the database, more than $90 \%$ of the PHIL tests are voltage-type, mainly due to the fact that the majority of the HUTs are current sources.

It is expected that this online database will be a useful tool which helps and boosts the improvement of the Smart Grid. Further steps could be the development of a website where laboratories could upload the information, source code, audiovisual, etc. of their experiments in a more operative open-platform, improving the reproducibility of the experiments.

Author Contributions: Conceptualization, E.G.-M., J.F.S. and J.M.-C.; methodology, E.G.-M., J.F.S., J.M.-C. and J.M.P.; investigation, E.G.-M.; resources, E.G.-M.; writing—original draft preparation, E.G.-M.; writing-review and editing, E.G.-M., J.F.S., J.M.-C. and J.M.P.; and supervision, J.F.S., J.M.-C. and J.M.P. All authors have read and agreed to the published version of the manuscript.

Funding: This research was funded by the CERVERA programme of CDTI, the Industrial and Technological Development Centre of Spain, under the research Project ENERISLA (CER-20191002).

Conflicts of Interest: The authors declare no conflict of interest.

\section{Abbreviations}

The following abbreviations are used in this manuscript:

$\begin{array}{ll}\text { ADC } & \text { Analog-to-Digital Converter } \\ \text { CPU } & \text { Central Processing Unit } \\ \text { DAC } & \text { Digital-to-Analog Converter } \\ \text { DIM } & \text { Damping Impedance Method } \\ \text { DSP } & \text { Digital Signal Processor } \\ \text { EMC } & \text { Electromagnetic Compatibility } \\ \text { FPGA } & \text { Field-Programmable Gate Array } \\ \text { PV } & \text { Photovoltaic } \\ \text { THD } & \text { Total Harmonic Distortion }\end{array}$




\section{References}

1. Siano, P. Demand response and smart grids-A survey. Renew. Sustain. Energy Rev. 2014, 30, 461-478. [CrossRef]

2. European Technology Platform SmartGrids. SmartGrids SRA 2035 Strategic Research Agenda Update of the SmartGrids SRA 2007 for the Needs by the Year 2035; Smart Grids European Technology Platform. 2012. Available online: https:/ / www.etip-snet.eu/wp-content/uploads/2017/04/sra2035.pdf (accessed on 14 January 2020).

3. Monti, A.; Ponci, F. Power Grids of the Future: Why Smart Means Complex. In Proceedings of the Complexity in Engineering (COMPENG '10), Rome, Italy, 22-24 February 2010; pp. 7-11. [CrossRef]

4. Liserre, M.; Sauter, T.; Hung, J.Y. Future Energy Systems: Integrating Renewable Energy Sources into the Smart Power Grid Through Industrial Electronics. IEEE Ind. Electron. Mag. 2010, 4, 18-37. [CrossRef]

5. Slootweg, H. Smart Grids-The future or fantasy? In Proceedings of the Smart Metering-Making It Happen, 2009 IET, London, UK, 19 February 2009; pp. 1-19. [CrossRef]

6. Strasser, T.; Pröstl Andrén, F.; Lauss, G.; Bründlinger, R.; Brunner, H.; Moyo, C.; Seitl, C.; Rohjans, S.; Lehnhoff, S.; Palensky, P.; et al. Towards holistic power distribution system validation and testing-an overview and discussion of different possibilities. E E I Elektrotechnik Und Informationstechnik 2017, 134, 71-77. [CrossRef]

7. Mylonas, E.; Tzanis, N.; Birbas, M.; Birbas, A. An Automatic Design Framework for Real-Time Power System Simulators Supporting Smart Grid Applications. Electronics 2020, 9, 299. [CrossRef]

8. Tuballa, M.L.; Abundo, M.L. A review of the development of Smart Grid technologies. Renew. Sustain. Energy Rev. 2016, 59, 710-725. [CrossRef]

9. Vijay, A.S.; Doolla, S.; Chandorkar, M.C. Real-Time Testing Approaches for Microgrids. IEEE J. Emerg. Sel. Top. Power Electron. 2017, 5, 1356-1376. [CrossRef]

10. Mariachet, J.E.; Matas, J.; Martín, H.; Li, M.; Guan, Y.; Guerrero, J.M. A power calculation algorithm for single-phase droop-operated-inverters considering linear and nonlinear loads HIL-assessed. Electronics 2019, 8, 1366. [CrossRef]

11. Huo, Y.; Gruosso, G. Ancillary service with grid connected PV: A real-time hardware-in-the-loop approach for evaluation of performances. Electronics 2019, 8, 809. [CrossRef]

12. Salcedo, R.; Nowocin, J.K.; Smith, C.L.; Rekha, R.P.; Limpaecher, E.R.; La Penta, J. Development of a Real-Time Hardware- in-the-Loop Power Systems Simulation Platform to Evaluate Commercial Microgrid Controllers. Technical Report February, Lincoln Laboratory-Massachusetts Institute of Technology. Available online: http:/ / www.dtic.mil/docs/citations/ADA635943 (accessed on 14 January 2020).

13. Carne, G.D.; Langwasser, M.; Gao, X.; Buticchi, G.; Liserre, M. Power-Hardware-In-Loop Setup for Power Electronics Tests. In Proceedings of the PCIM Europe 2017; International Exhibition and Conference for Power Electronics, Intelligent Motion, Renewable Energy and Energy Management, Nuremberg, Germany, 16-18 May 2017; pp. 1-7.

14. Kashani, M.G.; Pulakhandam, H.; Bhattacharya, S.; Katiraei, F.; Kaiser, D. Design considerations and test setup assessment for power hardware in the loop testing. In Proceedings of the 2017 IEEE Industry Applications Society Annual Meeting, Cincinnati, OH, USA, 1-5 OOctober 2017; pp. 1-8. [CrossRef]

15. Torres-Olguin, R.E.; Endegnanew, A.G.; D'Arco, S. Power-hardware-in-the-loop approach for emulating an offshore wind farm connected with a VSC-based HVDC. In Proceedings of the 2017 IEEE Conference on Energy Internet and Energy System Integration (EI2), Beijing, China, 26-28 November 2017; pp. 1-6. [CrossRef]

16. Lemaire, M.; Pammer, G.; Black, B. Smarter drives need smarter development. In Proceedings of the 2016 IEEE Transportation Electrification Conference and Expo (ITEC), Dearborn, MI, USA, 27-29 June 2016; pp. 1-63. [CrossRef]

17. Amitkumar, K.S.; Kaarthik, R.S.; Pillay, P. A versatile power-hardware-in-the-loop based emulator for rapid testing of electric drives. In Proceedings of the 2017 IEEE Energy Conversion Congress and Exposition (ECCE), Cincinnati, OH, USA, 1-5 October 2017; pp. 5468-5474. [CrossRef]

18. Orr, M. Selecting a Linear or PWM Power Source. Technical Report. Available online: https: //www.testworld.com/wp-content/uploads/Selecting-a-Linear-or-PWM-Power-Source.pdf (accessed on 14 January 2020). 
19. Lehfuss, F.; Lauss, G.; Kotsampopoulos, P.; Hatziargyriou, N.; Crolla, P.; Roscoe, A. Comparison of multiple power amplification types for power Hardware-in-the-Loop applications. In Proceedings of the 2012 Complexity in Engineering (COMPENG), Aachen, Germany, 11-13 June 2012; pp. 1-6. [CrossRef]

20. Ren, W.; Steurer, M.; Baldwin, T.L. An effective method for evaluating the accuracy of Power Hardware-in-the-Loop simulations. In Proceedings of the Industrial and Commercial Power Systems Technical Conference (ICPS 2008. IEEE/IAS), Clearwater Beach, FL, USA, 4-8 May 2008; pp. 1-6. [CrossRef]

21. Ebe, F.; Idlbi, B.; Stakic, D.E.; Chen, S.; Kondzialka, C.; Casel, M.; Heilscher, G.; Seitl, C.; Bründlinger, R.; Strasser, T.I. Comparison of power hardware-in-the-loop approaches for the testing of smart grid controls. Energies 2018, 11, 3381. [CrossRef]

22. Bélanger, J.; Dufour, C.; Schoen, L. eMEGAsim: An Open High-Performance Architecture and Specification. In Proceedings of the International Conference on Power Systems (ICPS'07), Bangalore, India, 12-14 December 2007; pp. 1-6.

23. Faruque, M.D.O.; Strasser, T.; Lauss, G.; Jalili-Marandi, V.; Forsyth, P.; Dufour, C.; Dinavahi, V.; Monti, A.; Kotsampopoulos, P.; Martinez, J.A.; et al. Real-Time Simulation Technologies for Power Systems Design, Testing, and Analysis. IEEE Power Energy Technol. Syst. J. 2015, 2, 63-73. [CrossRef]

24. Westermann, D.; Kratz, M. A Real-Time Development Platform for the Next Generation of Power System Control Functions. IEEE Trans. Ind. Electron. 2010, 57, 1159-1166. [CrossRef]

25. Ocnasu, D. Modélisation, Commande et Simulation Temps-Réel Hybride des Systèmes de Génération Non Conventionnels. Ph.D. Thesis, Université Joseph-Fourier-Grenoble I, Grenoble, France, 2008.

26. Vandewalle, P.; Kovacevic, J.; Vetterli, M. Reproducible research in signal processing. IEEE Signal Process. Mag. 2009, 26, 37-47. [CrossRef]

27. Ren, W.; Sloderbeck, M.; Steurer, M.; Dinavahi, V.; Noda, T.; Filizadeh, S.; Chevrefils, a.R.; Matar, M.; Iravani, R.; Dufour, C.; et al. Interfacing Issues in Real-Time Digital Simulators. IEEE Trans. Power Deliv. 2011, 26, 1221-1230. [CrossRef]

28. De Jong, E.; de Graff, R.; Vassen, P.; Crolla, P.; Roscoe, A.; Lefuss, F.; Lauss, G.; Kotsampopoulos, P.; Gafaro, F. European White Book on Real-Time Power Hardware in the Loop Testing. DERlab Report No. R- 005.0, January 2012. Available online: https:/ / pureportal.strath.ac.uk/en/publications/european-white-book-onreal-time-power-hardware-in-the-loop-testi (accessed on 14 January 2020).

29. Guillaud, X.; Faruque, M.O.; Teninge, A.; Hariri, A.H.; Vanfretti, L.; Paolone, M.; Dinavahi, V.; Mitra, P.; Lauss, G.; Dufour, C.; et al. Applications of Real-Time Simulation Technologies in Power and Energy Systems. IEEE Power Energy Technol. Syst. J. 2015, 1. [CrossRef]

30. Edrington, C.S.; Steurer, M.; Langston, J.; El-Mezyani, T.; Schoder, K. Role of Power Hardware in the Loop in Modeling and Simulation for Experimentation in Power and Energy Systems. Proc. IEEE 2015, 1-9. [CrossRef]

31. Lauss, G.; Faruque, M.; Schoder, K.; Dufour, C.; Viehweider, A.; Langston, J. Characteristics and Design of Power Hardware-in-the-Loop Simulations for Electrical Power Systems. IEEE Trans. Ind. Electron. 2015, 1. [CrossRef]

32. Mikkili, S.; Panda, A.; Prattipati, J. Review of Real-Time Simulator and the Steps Involved for Implementation of a Model from MATLAB/SIMULINK to Real-Time. J. Inst. Eng. India Ser. B 2014, 1-18. [CrossRef]

33. García-Martínez, E.; Sanz, J.F.; Muñoz-Cruzado, J.; Perié, J.M. Online database of Power Hardware In-the-Loop tests (article in press). Data Brief 2020. [CrossRef]

34. Opal-RT Technologies. Available online: https://www.opal-rt.com (accessed on 14 January 2020).

35. Seitl, C.; Kathan, J.; Lauss, G.; Lehfuss, F. Power hardware-in-the-loop implementation and verification of a real time capable battery model. In Proceedings of the 2014 IEEE 23rd International Symposium on Industrial Electronics (ISIE), Istanbul, Turkey, 1-4 June 2014; pp. 2285-2290. [CrossRef]

36. Craciun, O.; Florescu, A.; Munteanu, I.; Bratcu, A.I.; Bacha, S.; Radu, D. Hardware-in-the-loop simulation applied to protection devices testing. Int. J. Electr. Power Energy Syst. 2014, 54, 55-64. [CrossRef]

37. Lehfuss, F.; Lauss, G.; Strasser, T. Implementation of a multi-rating interface for Power-Hardware-in-the-Loop simulations. In Proceedings of the IECON 2012-38th Annual Conference on IEEE Industrial Electronics Society, Montreal, QC, Canada, 25-28 October 2012; pp. 4777-4782. [CrossRef]

38. Greenwood, D.M.; Lim, K.Y.; Patsios, C.; Lyons, P.F.; Lim, Y.S.; Taylor, P.C. Frequency response services designed for energy storage. Appl. Energy 2017, 203, 115-127. [CrossRef] 
39. Ye, W.; Delille, G.; Guillaud, X.; Colas, F.; Francois, B. Real-time simulation: The missing link in the design process of advanced grid equipment. In Proceedings of the 2010 IEEE Power and Energy Society General Meeting, Providence, RI, USA, 25-29 July 2010; pp. 1-8. [CrossRef]

40. Lundstrom, B.; Palmintier, B.; Rowe, D.; Ward, J.; Moore, T. Trans-oceanic remote power hardware-in-the-loop: Multi-site hardware, integrated controller, and electric network co-simulation. IET Gener. Transm. Distrib. 2017, 11, 4688-4701. [CrossRef]

41. Nagarajan, A.; Nelson, A.; Prabakar, K.; Hoke, A.; Asano, M.; Ueda, R.; Nepal, S. Network reduction algorithm for developing distribution feeders for real-time simulators. In Proceedings of the 2017 IEEE Power \& Energy Society General Meeting, Chicago, IL, USA, 16-20 July 2017; pp. 1-5. [CrossRef]

42. Hoke, A.; Nelson, A.; Chakraborty, S.; Bell, F.; McCarty, M. An Islanding Detection Test Platform for Multi-Inverter Islands using Power HIL. IEEE Trans. Ind. Electron. 2018, 1. [CrossRef]

43. Feng, G.; Herrera, L.; Alsolami, M.; He, L.; Pu, X.; Xintong, L.; Andong, L.; Jin, W.; Zhijun, L. Design and development of a reconfigurable hybrid Microgrid testbed. In Proceedings of the 2013 IEEE Energy Conversion Congress and Exposition (ECCE), Denver, CO, USA, 15-19 September 2013; pp. 1350-1356. [CrossRef]

44. Craciun, O.; Florescu, A.; Munteanu, I.; Bacha, S.; Bratcu, A.I.; Radu, D. Protection devices testing based on power-hardware-in-the-loop simulation. In Proceedings of the IECON 2011-37th Annual Conference on IEEE Industrial Electronics Society, Melbourne, Australia, 7-10 November 2011; pp. 3736-3741. [CrossRef]

45. Seitl, C.; Kathan, J.; Lauss, G.; Lehfuss, F. Selection and implementation of a generic battery model for PHIL applications. In Proceedings of the Industrial Electronics Society, IECON 2013-39th Annual Conference of the IEEE, Vienna, Austria, 10-13 November 2013; pp. 5412-5417. [CrossRef]

46. Yamane, A.; Li, W.; Belanger, J.; Ise, T.; Iyoda, I.; Aizono, T.; Dufour, C. A Smart Distribution Grid Laboratory. In Proceedings of the IECON 2011-37th Annual Conference on IEEE Industrial Electronics Society, Melbourne, Australia, 7-10 November 2011; pp. 3708-3712. [CrossRef]

47. RTDS Technologies. Available online: https://www.rtds.com/ (accessed on 14 January 2020).

48. Ren, W. Accuracy Evaluation of Power Hardware-in-the-Loop Simulation. Ph.D. Thesis, Florida State University, Tallahassee, FL, USA, 2007.

49. Nzimako, O.; Wierckx, R. Stability and accuracy evaluation of a power hardware in the loop (PHIL) interface with a photovoltaic micro-inverter. In Proceedings of the IECON 2015-41st Annual Conference of the IEEE Industrial Electronics Society, Yokohama, Japan, 9-12 November 2015; pp. 5285-5291. [CrossRef]

50. Lauss, G.; Lehfuss, F.; Bletterie, B.; Strasser, T.; Brundlinger, R. Examination of LV grid phenomena by means of PHIL testing. In Proceedings of the IECON 2012-38th Annual Conference on IEEE Industrial Electronics Society, Monteral, QC, Canada, 25-28 October 2012; pp. 4771-4776. [CrossRef]

51. Kotsampopoulos, P.; Kleftakis, V.; Messinis, G.; Hatziargyriou, N. Design, development and operation of a PHIL environment for Distributed Energy Resources. In Proceedings of the IECON 2012-38th Annual Conference on IEEE Industrial Electronics Society, Monteral, QC, Canada, 25-28 October 2012; pp. 4765-4770. [CrossRef]

52. Pokharel, M.; Ho, C.N.M. Stability study of power hardware in the loop (PHIL)simulations with a real solar inverter. In Proceedings of the IECON 2017-43rd Annual Conference of the IEEE Industrial Electronics Society, Beijing, China, 5-8 November 2017; pp. 2701-2706. [CrossRef]

53. Langston, J.; Schoder, K.; Steurer, M.; Faruque, O.; Hauer, J.; Bogdan, F.; Bravo, R.; Mather, B.; Katiraei, F. Power hardware-in-the-loop testing of a $500 \mathrm{~kW}$ photovoltaic array inverter. In Proceedings of the IECON 2012 - 38th Annual Conference on IEEE Industrial Electronics Society, Monteral, QC, Canada, 25-28 October 2012; pp. 4797-4802. [CrossRef]

54. Kotsampopoulos., P.; Kapetanaki., A.; Messinis., G.; Kleftakis., V.; Hatziargyriou, N. A Power-Hardware-in-the-loop facility for microgrids. Int. J. Renew. Energy Technol. 2012, 9, 89-104.

55. Karapanos, V.; de Haan, S.; Zwetsloot, K. Real time simulation of a power system with VSG hardware in the loop. In Proceedings of the IECON 2011-37th Annual Conference on IEEE Industrial Electronics Society, Melbourne, Australia, 7-10 November 2011; pp. 3748-3754. [CrossRef]

56. Schacherer, C.; Langston, J.; Steurer, M.; Noe, M. Power Hardware-in-the-Loop Testing of a YBCO Coated Conductor Fault Current Limiting Module. IEEE Trans. Appl. Supercond. 2009, 19, 1801-1805. [CrossRef] 
57. Yost, K.; Langston, J.; Steurer, M.; Schoder, K.; Hauer, J.; Bogdan, F.; Leonard, I.; Chiocchio, T.; Sloderbeck, M.; Farrell, A.; et al. Megawatt Scale Hardware-in-the-Loop Testing of a High Speed Generator. Technical Report 88. Available online: http://www.dtic.mil/docs/citations/ADA558395 (accessed on 14 January 2020).

58. Langston, J.; Bogdan, F.; Hauer, J.; Schoder, K.; Steurer, M.; Dalessandro, D.; Fikse, T.; Cherry, J.; Gonstead, S. Megawatt-scale power hardware-in-the-loop simulation testing of a power conversion module for naval applications. In Proceedings of the 2015 IEEE Electric Ship Technologies Symposium (ESTS), Old Town Alexandria, VA, USA, 21-24 June 2015; pp. 268-275. [CrossRef]

59. Kim, E.S.; Kim, D.W. Performance testing of Grid-connected photovoltaic inverter based on an integrated electronic protection device. In Proceedings of the 2009 Transmission and Distribution Conference and Exposition: Asia and Pacific, Seoul, Korea, 26-30 October 2009; pp. 1-4. [CrossRef]

60. Mao, C.; Leng, F.; Li, J.; Zhang, S.; Zhang, L.; Mo, R.; Wang, D.; Zeng, J.; Chen, X.; An, R.; et al. A 400-V/50-kVA Digital-Physical Hybrid Real-Time Simulation Platform for Power Systems. IEEE Trans. Ind. Electron. 2018, 65, 3666-3676. [CrossRef]

61. Vodyakho, O.; Edrington, C.S.; Steurer, M.; Azongha, S.; Fleming, F. Synchronization of three-phase converters and virtual microgrid implementation utilizing the Power-Hardware-in-the-Loop concept. In Proceedings of the 2010 Twenty-Fifth Annual IEEE Applied Power Electronics Conference and Exposition (APEC), Palm Springs, CA, USA, 21-25 February 2010; pp. 216-222. [CrossRef]

62. Kotsampopoulos, P.; Kleftakis, V.; Hatziargyriou, N. Laboratory Education of Modern Power Systems using PHIL Simulation. IEEE Trans. Power Syst. 2016, 1. [CrossRef]

63. Averous, N.R.; Stieneker, M.; Kock, S.; Andrei, C.; Helmedag, A.; Doncker, R.W.D.; Hameyer, K.; Jacobs, G.; Monti, A. Development of a 4 MW Full-Size Wind-Turbine Test Bench. IEEE J. Emerg. Sel. Top. Power Electron. 2017, 5, 600-609. [CrossRef]

64. Steurer, M.M.; Schoder, K.; Faruque, O.; Soto, D.; Bosworth, M.; Sloderbeck, M.; Bogdan, F.; Hauer, J.; Winkelnkemper, M.; Schwager, L.; et al. Multifunctional Megawatt-Scale Medium Voltage DC Test Bed Based on Modular Multilevel Converter Technology. IEEE Trans. Transp. Electrif. 2016, 2, 597-606. [CrossRef]

65. Hong, Q.; Abdulhadi, I.; Roscoe, A.; Booth, C. Application of a MW-scale motor-generator set to establish power-hardware-in-the-loop capability. In Proceedings of the 2017 IEEE PES Innovative Smart Grid Technologies Conference Europe (ISGT-Europe), Torino, Italy, 26-29 September 2017; pp. 1-6. [CrossRef]

66. Maniatopoulos, M.; Lagos, D.; Kotsampopoulos, P.; Hatziargyriou, N. Combined control and power hardware in-the-loop simulation for testing smart grid control algorithms. IET Gener. Transm. Distrib. 2017, 11, 3009-3018. [CrossRef]

67. Kashani, M.G.; Bhattacharya, S.; Matamoros, J.; Kaiser, D.; Cespedes, M. Voltage regulation with autonomous distributed smart inverters in a low voltage network. In Proceedings of the 2017 IEEE Power and Energy Society General Meeting, Chicago, IL, USA, 16-20 July 2017; pp. 1-5. [CrossRef]

68. Roscoe, A.J.; Mackay, A.; Burt, G.M.; McDonald, J.R. Architecture of a Network-in-the-Loop Environment for Characterizing AC Power-System Behavior. IEEE Trans. Ind. Electron. 2010, 57, 1245-1253. [CrossRef]

69. Ren, W.; Steurer, M.; Baldwin, T.L. Improve the Stability and the Accuracy of Power Hardware-in-the-Loop Simulation by Selecting Appropriate Interface Algorithms. In Proceedings of the Industrial and Commercial Power Systems Technical Conference (ICPS 2007. IEEE/IAS), Edmonton, AB, Canada, 6-11 May 2007; pp. 1-7. [CrossRef]

70. Ren, W.; Steurer, M.; Woodruff, S. Applying Controller and Power Hardware-in-the-Loop Simulation in Designing and Prototyping Apparatuses for Future All Electric Ship. In Proceedings of the Electric Ship Technologies Symposium (ESTS '07. IEEE), Arlington, VA, USA, 21-23 May 2007; pp. 443-448. [CrossRef]

71. Fleming, F.; Edrington, C.S.; Steurer, M.; Vodyakho, O. Development and implementation of a $25 \mathrm{~kW}$ virtual induction machine test bed utilizing the power-hardware-in-the-loop concept. In Proceedings of the IEEE International Electric Machines and Drives Conference (IEMDC '09), Miami, FL, USA, 3-6 May 2009; pp. 1161-1166. [CrossRef]

72. Vodyakho, O.; Fleming, F.; Steurer, M.; Edrington, C. Implementation of a virtual induction machine test bed utilizing the power hardware-in-the-loop concept. In Proceedings of the 2011 IEEE Electric Ship Technologies Symposium (ESTS), Alexandria, VA, USA, 10-13 April 2011; pp. 52-55. [CrossRef] 
73. Adler, F.; Benigni, A.; Stagge, H.; Monti, A.; Doncker, R.W.D. A new versatile hardware platform for digital real-time simulation: Verification and evaluation. In Proceedings of the 2012 IEEE 13th Workshop on Control and Modeling for Power Electronics (COMPEL), Kyoto, Japan, 10-13 June 2012; pp. 1-8. [CrossRef]

74. Monti, A.; D'Arco, S.; Deshmukh, A. A new architecture for low cost Power Hardware in the Loop testing of power electronics equipments. In Proceedings of the IEEE International Symposium on Industrial Electronics, ISIE 2008, Cambridge, UK, 30 June-2 July 2008; pp. 2183-2188. [CrossRef]

75. Hypersim-Hydro Québec. Available online: http://www.hydroquebec.com/international/en/ technology/grid-simulation.html (accessed on 14 January 2020).

76. Dione, M.; Sirois, F.; Bonnard, C.H. Evaluation of the Impact of Superconducting Fault Current Limiters on Power System Network Protections Using a RTS-PHIL Methodology. IEEE Trans. Appl. Supercond. 2011, 21, 2193-2196. [CrossRef]

77. Ur Rehman, N.; Khan, A.H. RTLinux based Simulator for Hardware-in-the Loop Simulations. In Proceedings of the International Bhurban Conference on Applied Sciences and Technology (IBCAST 2007), Islamabad, Pakistan, 8-11 January 2007; pp. 78-81. [CrossRef]

78. Marti, J.R.; Linares, L.R.; Calvino, J.; Dommel, H.W.; Lin, J. OVNI: An object approach to real-time power system simulators. In Proceedings of the 1998 International Conference on Power System Technology (POWERCON '98), Beijing, China, 18-21 August 1998; Volume 2, pp. 977-981. [CrossRef]

79. Weidong, Z.; Pekarek, S.; Jatskevich, J.; Wasynczuk, O.; Delisle, D. A model-in-the-loop interface to emulate source dynamics in a zonal DC distribution system. IEEE Trans. Power Electron. 2005, 20, 438-445. [CrossRef]

80. Palmintier, B.; Lundstrom, B.; Chakraborty, S.; Williams, T.; Schneider, K.; Chassin, D. A Power-Hardware-in-the-Loop Platform with Remote Distribution Circuit Co-simulation. IEEE Trans. Ind. Electron. 2014, 1. [CrossRef]

81. Zhou, Y.; Lin, J.; Song, Y.; Cai, Y.; Liu, H. A power hardware-in-loop based testing bed for auxiliary active power control of wind power plants. Electr. Power Syst. Res. 2015, 124, 10-17. [CrossRef]

82. Marin, M.; Benigni, A.; Monti, A. New Approach to Parallel Simulation of Large Power Systems. In Proceedings of the 2011 Grand Challenges on Modeling and Simulation Conference (GCMS '11), The Hague, The Netherlands, 27-29 June 2011; Society for Modeling and Simulation International: Vista, CA, 2011; pp. 252-257.

83. Fleming, F. Real-Time Switched Reluctance Machine Emulation via Magnetic Equivalent Circuits. Ph.D. Thesis, Florida State University, Tallahassee, FL, USA, 2014.

84. Dinavahi, V.; Iravani, R.; Bonert, R. Design of a real-time digital Simulator for a D-STATCOM system. IEEE Trans. Ind. Electron. 2004, 51, 1001-1008. [CrossRef]

85. Sehwa, C.; Sanggi, K.; So-Yeon, K.; Seung-Ki, S. Small scaled Power Hardware-In-The Loop and control method of ship integrated power system with active front end converter and battery energy storage system using low cost multicore DSP. In Proceedings of the 2014 16th European Conference on Power Electronics and Applications (EPE'14-ECCE Europe), Piscataway, NJ, USA, 26-28 August 2014; pp. 1-10. [CrossRef]

86. Goyal, S.; Ledwich, G.; Ghosh, A. Power Network in Loop: A Paradigm for Real-Time Simulation and Hardware Testing. IEEE Trans. Power Deliv. 2010, 25, 1083-1092. [CrossRef]

87. Slater, H.J.; Atkinson, D.J.; Jack, A.G. Real-time emulation for power equipment development. II. The virtual machine. IEE Proc. Electr. Power Appl. 1998, 145, 153-158. [CrossRef]

88. Rosa, H.R.A.; Silva, B.E.M.; Campos, F.C.M.; Santana, A.S.R.; Rodrigues, A.W.; Morais, M.F.L.; Seleme, S.I., Jr. SHIL and DHIL Simulations of Nonlinear Control Methods Applied for Power Converters Using Embedded Systems. Electronics 2018, 7, 241. [CrossRef]

89. Parma, G.; Dinavahi, V. Real-Time Digital Hardware Simulation of Power Electronics and Drives. In Proceedings of the Power Engineering Society General Meeting, Tampa, FL, USA, 24-28 June 2007; p. 1. [CrossRef]

90. Gehrke, C.S.; Oliveira, A.C.; Lima, A.M.N.; da Silva, I. Power hardware-in-the-loop (PHIL) based on FPGA. Power Electron. Conf. COBEP 2013, 3, 298-304. [CrossRef]

91. Matar, M.; Iravani, R. Massively Parallel Implementation of AC Machine Models for FPGA-Based Real-Time Simulation of Electromagnetic Transients. IEEE Trans. Power Deliv. 2011, 26, 830-840. [CrossRef]

92. Washington, C.; Dolman, J. Creating next generation HIL simulators with FPGA technology. In Proceedings of the 2010 IEEE AUTOTESTCON, Orlando, FL, USA, 13-16 September 2010; pp. 1-6. [CrossRef] 
93. Liu, J.; Dinavahi, V. A Real-Time Nonlinear Hysteretic Power Transformer Transient Model on FPGA. IEEE Trans. Ind. Electron. 2014, 61, 3587-3597. [CrossRef]

94. Matar, M.; Iravani, R. FPGA Implementation of the Power Electronic Converter Model for Real-Time Simulation of Electromagnetic Transients. IEEE Trans. Power Deliv. 2010, 25, 852-860. [CrossRef]

95. Schoder, K.; Langston, J.; Steurer, M. Commissioning of MW-scale Power Hardware-in-the-Loop interfaces for experiments with AC/DC Converters. In Proceedings of the Industrial Electronics Society, IECON 2013-39th Annual Conference of the IEEE, Vienna, Austria, 10-13 November 2013; pp. 5364-5367. [CrossRef]

96. Koralewicz, P.; Gevorgian, V.; Wallen, R. Multi-megawatt-scale fower-hardware-in-the-loop interface for testing ancillary grid services by converter-coupled generation. In Proceedings of the 2017 IEEE 18th Workshop on Control and Modeling for Power Electronics (COMPEL), 9-12 July 2017; pp. 1-8. [CrossRef]

97. Crolla, P.; Roscoe, A.J.; Dysko, A.; Burt, G.M. Methodology for testing loss of mains detection algorithms for microgrids and distributed generation using real-time power hardware-in-the-loop based technique. In Proceedings of the 2011 IEEE 8th International Conference on Power Electronics and ECCE Asia (ICPE and ECCE), Jeju, Korea, 30 May-3 June 2011; pp. 833-838. [CrossRef]

98. Si, G.; Cordier, J.; Kennel, R. Development of a power-hardware-in-the-loop application-Power grid emulator by using voltage source inverter cumulation. In Proceedings of the 2015 IEEE Applied Power Electronics Conference and Exposition (APEC), Charlotte, NC, USA, 15-19 March 2015; pp. 2181-2188. [CrossRef]

99. Carne, G.D.; Buticchi, G.; Kerekes, T.; Liserre, M. Power-Hardware-In-Loop harmonic analysis of a Smart Transformer-fed distribution grid. In Proceedings of the IECON 2016-42nd Annual Conference of the IEEE Industrial Electronics Society, Florence, Italy, 23-26 October 2016; pp. 7004-7009. [CrossRef]

100. AE Techron. Available online: http:/ / aetechron.com/ (accessed on 14 January 2020).

101. Puisssance+. Available online: http:/ / www.puissanceplus.com (accessed on 14 January 2020).

102. Spitzenberger and Spies GmbH and Co. Available online: http:/ / www.spitzenberger.de (accessed on 14 January 2020).

103. NF Corporation. Available online: https://www.nfcorp.co.jp/english/ (accessed on 14 January 2020).

104. Power Electronic Building Blocks (PEBB)_ABB. Available online: https://new.abb.com/power-convertersinverters/ (accessed on 14 January 2020).

105. Regatron AG. Available online: www.regatron.com (accessed on 14 January 2020).

106. Triphase. Available online: https://triphase.com/ (accessed on 14 January 2020).

107. Compiso-Egston. Available online: https://www.egstonpower.com/system/ (accessed on 14 January 2020).

108. MX-45-Ametek. Available online: https://www.powerandtest.com/power/ac-power-sources/mx-series (accessed on 14 January 2020).

109. Huber, J.E.; Kolar, J.W.; Pammer, G. Hybrid inverter concept for extreme bandwidth high-power AC source. Electron. Lett. 2017, 53, 947-949. [CrossRef]

110. Boillat, D.O. Modular High Bandwidth Switch-Mode Three-Phase AC Voltage Source. Ph.D. Thesis, ETH, Zurich, Switzerland, 2016.

111. Benigni, A.; Helmedag, A.; Abdalrahman, A.M.E.A.E.; Pilatowicz, G.; Monti, A. FlePS: A power interface for Power Hardware In the Loop. In Proceedings of the 2011-14th European Conference onPower Electronics and Applications (EPE 2011), Birmingham, UK, 30 August-1 September 2011; pp. 1-10.

112. Kolb, J.; Kammerer, F.; Schmitt, A.; Gommeringer, M.; Braun, M. The Modular Multilevel Converter as Universal High-Precision 3AC Voltage Source for Power Hardware-in-the-Loop Systems. In Proceedings of the PCIM Europe 2014; International Exhibition and Conference for Power Electronics, Intelligent Motion, Renewable Energy and Energy Management, Nuremberg, Germany, 20-22 May 2014; pp. 1-8.

113. Sun, J.; Yin, C.; Gong, J.; Chen, Y.; Liao, Z.; Zha, X. A Stable and Fast-Transient Performance Switched-Mode Power Amplifier for a Power Hardware in the Loop (PHIL) System. Energies 2017, 10, 1569. [CrossRef]

114. Brandl, R. Operational Range of Several Interface Algorithms for Different Power Hardware-In-The-Loop Setups. Energies 2017, 10, 1946. [CrossRef]

115. Riccobono, A.; Helmedag, A.; Berthold, A.; Averous, N.R.; De Doncker, R.W.; Monti, A. Stability and Accuracy Considerations of Power Hardware- in-the-Loop Test Benches for Wind Turbines. IFAC-PapersOnLine 2017, 50, 10977-10984. [CrossRef] 
116. Jung, J.H. Power hardware-in-the-loop simulation (PHILS) of photovoltaic power generation using real-time simulation techniques and power interfaces. J. Power Sources 2015, 285, 137-145. [CrossRef]

117. Christie, R. 57 Bus Power Flow Test Case. Available online: https://labs.ece.uw.edu/pstca/pf57/pg tca57bus.htm (accessed on 14 January 2020).

(C) 2020 by the authors. Licensee MDPI, Basel, Switzerland. This article is an open access article distributed under the terms and conditions of the Creative Commons Attribution (CC BY) license (http:// creativecommons.org/licenses/by/4.0/). 